This PDF is a selection from a published volume from the National Bureau of Economic Research

Volume Title: Economic Aspects of Obesity

Volume Author/Editor: Michael Grossman and Naci H. Mocan, editors

Volume Publisher: University of Chicago Press

Volume ISBN: 0-226-31009-4

ISBN13: 978-0-226-31009-1

Volume URL: http://www.nber.org/books/gros09-1

Conference Date: November 10-11, 2008

Publication Date: April 2011

Chapter Title: Food Prices and the Dynamics of Body Weight Chapter Authors: Dana Goldman, Darius Lakdawalla, Yuhui Zheng

Chapter URL: http://www.nber.org/chapters/c11817

Chapter pages in book: $(65-90)$ 


\title{
Food Prices and the Dynamics of Body Weight
}

\author{
Dana Goldman, Darius Lakdawalla, and Yuhui Zheng
}

\subsection{Introduction}

A great many policy approaches to the obesity epidemic have been proposed. A popular choice among these has been the imposition of a "fat tax" on selected foods that are deemed to promote obesity, as a result of high caloric density, low nutritional value, or high fat content (Jacobson and Brownell 2000; Nestle and Jacobson 2000). In the year 2000, for example, there were nineteen states and cities in the United States that imposed taxes on less nutritious foods like soft drinks, sweets, or snack foods (Jacobson and Brownell 2000). In the past, policymakers viewed these primarily as "sin taxes" designed to raise revenue rather than influence health. Most localities use revenues for general purposes. Others earmark them for specific purposes, like violence prevention (Washington), Medicaid (Arkansas), or medical schools (West Virginia). Such taxes were strongly opposed by the soft drink and food industries. Perhaps as a result, twelve localities have reduced or repealed such taxes in recent years.

Understanding the public economics of fat taxes requires an understand-

Dana Goldman is a professor and the Norman Topping Chair in Medicine and Public Policy at the University of Southern California and a research associate of the National Bureau of Economic Research. Darius Lakdawalla is an associate professor in the University of Southern California (USC) School of Policy, Planning, and Development (SPPD), director of research at the USC Schaeffer Center for Health Policy and Economics, and a research associate of the National Bureau of Economic Research. Yuhui Zheng is a postdoctoral research fellow at the National Bureau of Economic Research.

We are grateful to participants at the November 2008 Economics of Obesity Conference, as well as Michael Anderson, Michael Grossman, and Bob Kaestner for comments. We thank the National Institute on Aging for funding. All errors are ours. The views expressed herein are those of the author(s) and do not necessarily reflect the views of the National Bureau of Economic Research. 
ing of how, or even whether, individuals respond to changes in food prices. Regardless of whether municipalities intend to influence health, there may be health effects that need to be quantified. To meet this public policy need, a literature on food prices and obesity has emerged in health economics. Chou, Grossman, and Saffer (2004) found that the real fast-food restaurant price, the real food-at-home price, and the real full-service restaurant price were negatively associated with weight in an adult population. Lakdawalla and Philipson (2002) found qualitatively similar, but larger, effects on a population of young adults. Another study found that the real price of fast-food is negatively related to body weight among adolescents, while the real price of fruits and vegetables food is positively associated (Auld and Powell 2008). Among U.S. children from kindergarten to the third grade, lower real food prices of fruits and vegetables are significantly associated with lower weight gain (Sturm and Datar 2005, 2008).

Economic theory suggests that food prices affect food intake. Biology suggests that food intake affects both the level of current weight, and the rate at which weight changes. Therefore, manipulating the price of food may have both short- and long-run consequences for body weight. This effect is reinforced by inertia in body weight (Heo, Faith, and Pietrobelli 2002).

Most of the economic literature to date has examined the contemporaneous relationship between food prices and body weight either in a crosssectional setting or panel data setting. ${ }^{1}$ However, the long-run consequences of food prices may be quite different.

To fill this gap in the literature, we study the short- and long-run body weight consequences of changing food prices. We use the Health and Retirement Study (HRS), a panel of U.S. adults aged fifty and over. The use of the HRS is motivated both by its panel features, which facilitate the study of long-run consequences, and by the particular importance of studying health and health care expenditures in this population.

The rest of the chapter is organized as follows: Section 3.2 outlines the conceptual framework. Section 3.3 describes the data, and Section 3.4 the methods. Section 3.5 reports the results, and Section 3.6 concludes.

\subsection{Conceptual Framework}

We conceptualize the determination of body weight as a dynamic problem, with body weight as a state variable and food intake as a control variable. Consider an individual who maximizes lifetime utility by choosing food consumption and nonfood consumption, subject to a budget constraint. Changes in body weight are driven by current food intake, and current body weight. Current body weight directly affects utility either by affecting health or body image. This problem is formalized as: 


$$
\begin{aligned}
& \max \int_{t_{0}}^{t_{1}} e^{-r t} U(W(t), F(t), C(t)) d t \\
& \text { s.t. } W^{\prime}=\frac{d W}{d t}=g(W(t), F(t)) \\
& W\left(t_{0}\right)=W_{0} \\
& t_{0}, t_{1} \text { fixed } \\
& C(t)+P_{t} F(t) \leq I_{t} .
\end{aligned}
$$

Variable $r$ is the one-period discount rate; $W(t)$ is body weight at time $t ; F(t)$ is the amount of food intake at time $t ; p_{t}$ is the relative price of food. Variable $C(t)$ is the nonfood consumption at time t; $I_{t}$ is the income; $C(t)$ can be written as $I_{t}-p_{t} F(t)$.

We assume that utility is concave in food intake $\left(U_{F F}<0\right)$, that eating more leads to weight gain $\left(g_{F}>0\right)$, and that a given level of food intake results in less weight gain for heavier people $\left(g_{W}<0\right)$.

The Hamiltonian for this optimal control problem is:

$$
H(t, W, F, \lambda)=e^{-r t} U\left(W(t), F(t), I_{t}-p_{t} F(t)\right)+\lambda g(W(t), F(t)) .
$$

If $W^{*}(t)$ and $F^{*}(t)$ maximize the objective function, the necessary conditions include:

$$
H_{F}=e^{-r t}\left(U_{W} W_{F}+U_{F}-p_{t} U_{C}\right)+\lambda g_{F}=0 .
$$

The second-order condition can be written as:

$$
H_{F F}=e^{-r t}\left(U_{W F} W_{F}+U_{W} W_{F F}+U_{F F}-p_{t} U_{C F}\right)+\lambda g_{F F}<0 .
$$

It is straightforward to show that the demand for food is downwardsloping in this model, or that $\partial F^{*} / \partial p_{t}<0 .{ }^{2}$ Second, since $g_{F}>0$, weight gain will be larger as $F^{*}(t)$ increases. Finally, the steady-state body weight will also rise with food consumption. ${ }^{3}$

Based on the analysis above, we raise the following two hypotheses that will be subject to empirical test:

1. Increases in the relative price of food are associated with lower rates of body weight gain.

2 . Increases in the relative price of food are associated with lower steadystate level of body weight.

2. Computing the derivative of equation (3) with respect to $p_{t}$, we obtain $H_{F F} \partial F^{*} / \partial p_{t}=e^{-r t} U_{C}$. According to (4), $H_{F F}<0$. Since $U_{C}>0$, it implies that $\partial F^{*} / \partial p_{t}<0$.

3 . Since $g_{W}<0$, body weight will increase at a diminishing rate until it reaches a steady state. This steady-state body weight $W_{s}$ will satisfy $g\left(W_{s}, F^{*}(t)\right)=0$. Differentiating this expression with respect to $F^{*}(t)$ yields: $g_{F}\left(W_{s}, F^{*}(t)\right)+g_{w}\left(W_{s}, F^{*}(t)\right) \partial W_{s} / \partial F^{*}(t)=0$. Since $g_{F}\left(W_{s}\right.$, $\left.F^{*}(t)\right)>0$, and $g_{w}\left(W_{s}, F^{*}(t)\right)<0$, it must be true that $\partial W_{s} \partial F^{*}(t)>0$. 


\subsection{Data}

\subsubsection{Health and Retirement Study Data}

We use the Health and Retirement Study (HRS), a biennial survey of the population over age fifty, to carry out the analysis. The original HRS cohort - first interviewed in 1992 - was a nationally representative sample of approximately 7,600 households ( $n=12,654$ individuals) with at least one member who was born between 1931 and 1941. In every interview wave, HRS respondents are asked detailed questions about demographics, employment, occupation, income and wealth, and health insurance. Questions were also asked about self-reported general health status, prevalence and incidence of chronic conditions, functional status and disability, and self-reported body height and weight. County residence is available also, on a restricted-use basis; this allows us to link geographical information on food prices, as discussed below.

Body mass index (BMI) in HRS is constructed from self-reported weight and height. Earlier research has identified systematic error in measurement for these variables; to address this issue, we employ the correction method developed by Cawley (1999). The Cawley procedure relies on the availability of external data on both actual and self-reported heights and weights. The relationship between the self-reported and actual numbers is then used to adjust the self-reported values.

Objectively measured height and weight data are available for a subsample of the HRS. In the year 2006, HRS randomly selected half its households and measured their weight and height. The self-reported weight and height is also available for these households. Using these variables, we run linear regressions of actual weight on reported weight and its square, age, and age squared, separately for the following eight subgroups: white male non-Hispanic, white female non-Hispanic, black male non-Hispanic, black female non-Hispanic, Hispanic male, Hispanic female, other male, and other female. Figure 3A.1 through 3A.4 show the relationship between predicted weight and height versus self-reported weight and height. Non-Hispanic white (male and female) and black female tend to underreport weight when self-reported weight is high. There is a slight overreport of height across all race-gender groups, especially among "other male."

\subsubsection{Food Price Data}

We obtain prices for food and other goods from the ACCRA Cost of Living data, published quarterly by the American Chamber of Commerce Researchers Association (ACCRA), for more than 200 cities. We use data from 1992 to 2003.

The ACCRA collects prices for fifty-nine distinct but standardized items, which are all listed in tables 3B.1 to 3B.3. Of the items listed, twenty-two are 
at-home food. Some examples include: $5 \mathrm{lb}$ bag of sugar, cane or beet; $3 \mathrm{lb}$ can of Crisco brand shortening; and 12 oz can of Minute Maid brand frozen concentrated orange juice. Prices for three fast-food items are reported, which include: a quarter-pound patty with cheese (McDonald's QuarterPounder with Cheese, where available); 12" to $13^{\prime \prime}$ thin crust cheese pizza (Pizza Hut or Pizza Inn, where available); and thigh and drumstick, with or without extras (Kentucky Fried Chicken or Church's where available). For each city, ACCRA collects mean prices for each of the fifty-nine items. It also reports the expenditure weight of each item in the budget of a nationally representative household with a "middle-management" lifestyle.

Since the ACCRA data are reported quarterly, we average prices over the available quarters to obtain annual prices. The ACCRA reports prices at the level of metropolitan areas, but the HRS data codes residence at the county level. Therefore, we use the population-weighted averages of city prices to construct prices at the county level. We calculate "real" prices by deflating using the Bureau of Labor Statistics (BLS) consumer price index for all goods.

Using the ACCRA data, we calculate the following prices: price per calorie, price of cigarettes, and price of gasoline.

\section{Individual Item Prices}

We use the price of cigarettes and of gasoline, as collected by ACCRA. The price of gasoline is the cash price at a self-service pump, if available, for one gallon of regular unleaded, national brand gasoline, inclusive of all taxes. The price of cigarettes is calculated as the price of a carton of Winston king-size $(85 \mathrm{~mm})$ cigarettes.

\section{Price Per Calorie}

A composite food price index like the price of food at home does not take into account differential impacts on body weight of consuming various foods. For example, using this price index, the impact of a 10 percent price increase in vegetables on body weight would be equal to that of a 10 percent increase in the price of butter, if the expenditure shares of the two goods are the same. A better alternative is to put more weight on foods that are more calorie-dense than others. Therefore, we construct a measure of the price per calorie. Increases in this index we interpret as relative increases in the price of high-calorie foods.

To construct the price per calorie variable, we first construct price per calorie for each food item in the ACCRA basket. This is given by the price per unit of food, divided by calories per unit of food. We obtain the data on calories from the United States Department of Agriculture (USDA) web site of "What's In The Foods You Eat Search Tool." ${ }^{4}$ For example, 100 
grams of ground beef contain 254 calories, and 100 grams of bananas have 90 calories.

The item prices are then aggregated to form a composite index of price per calorie. This index weights each food item by its share of calorie contribution to the mean basket of food consumption reported by ACCRA in its 1992 data. The index aggregates across all at-home food and fast-food items, using this weighting scheme.

Define calprice ${ }_{g t}$ as the index for price per calorie, for area $g$ at time $t$. This index aggregates across our twenty-five food items, indexed by $j$. Time measurement is normalized so that the base year of 1992 is written as $t=0$. Before describing the mathematical expression for the index, it helps to define the following auxiliary terms:

$p_{g j t}$ : Price per unit of food $j$, in area $g$, at time $t$

$k_{j}$ : calories per unit of food $j$

$w_{j 0}$ : expenditure share for food $j$, in base year

We can then define the calorie share of item $j$, in area $g$, during the base year, as follows:

$$
c_{g j 0} \equiv \frac{\left[\left(W_{j 0} / p_{g j 0}\right) k_{j}\right]}{\sum_{j=1}^{25}\left(W_{j 0} / p_{g j 0}\right) k_{j}} .
$$

Finally, this allows us to write the calorie-price index as:

$$
\text { calprice }_{g t}=\sum_{j=1}^{25} \frac{p_{g j t}}{k_{j}} c_{g j 0} \text {. }
$$

\subsubsection{Analytic Sample}

We begin with 9,733 HRS respondents born between 1931 and 1941, first interviewed in 1992, and with positive HRS sampling weight. Those who did not die or drop out of the sample were followed biennially until 2004. Due to the nature of the analysis, we exclude several segments of the sample. First, we exclude individuals residing in counties for which ACCRA collects no data. Second, we exclude individuals with missing values for any of the variables used in the regression analysis. Third, we exclude observations with nonadjacent waves of data. For example, if an individual was interviewed in wave 1 , wave 3 , and wave 4 , we exclude the wave 1 data, but retain the data from waves 3 and 4 . Finally, we exclude individuals who moved from one county to another. These individuals moved at some point between interviews, which are spaced twenty-four months apart. Given the substantial between-city variation in food prices, this induces considerable error in measuring the "true" price that the individual faces over the relevant time frame. The detailed sample selection process is shown in figure 3.1. There are 3,111 individuals included in the final analytic sample. Below, we investigate the possibility of sample selection bias. 


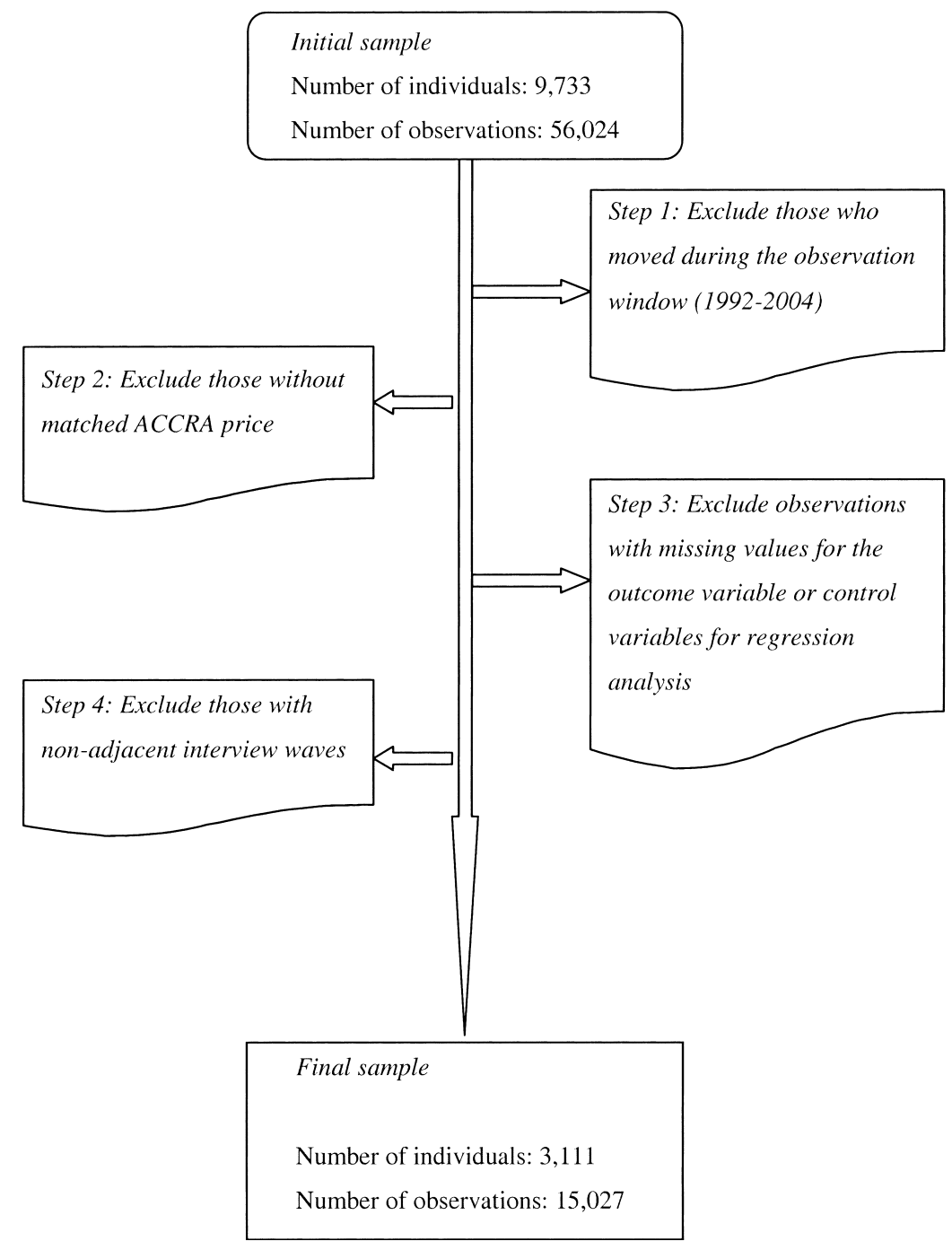

Fig. 3.1 Flow chart of forming the analytic sample

\subsection{Methods}

\subsubsection{Econometric Analysis}

The conceptual framework implies that current body weight is a function of past body weight, and factors that affect energy intake and energy expenditure. A reduced-form equation is the following dynamic linear panel model: 


$$
W_{i g t}=\beta_{0}+\sum_{k=0}^{t-1} \gamma_{k} W_{i g, k}+P_{g t} \beta_{1}+Z_{g t} \beta_{2}+X_{i g t} \beta_{3}+\alpha_{i}+\tau_{t}+\varepsilon_{i g t} .
$$

Variable $W_{i g t}$ is the weight for individual $i$ in geographic region $g$ at time $t$. Variables $W_{i g, k}$ are body weight in previous periods; more than one previous period could affect current body weight, but including too many periods will greatly reduce the sample size. We minimize the number of periods to include, while ensuring there is no serial correlation in the error term $\varepsilon_{i g t}$, which is a necessary assumption for the model estimation we will use. Variable $P_{g t}$ represents food prices; $Z_{g t}$ stands for other regional variables; $\alpha_{i}$ is individual fixed effect; while $\tau_{t}$ are year fixed effects. Since HRS is a biennial survey, to reflect prices during a two-year period, $P_{g t}$ is calculated as the average of the prices for the current year $t$ and the year before. There is one exception: the last year of HRS data in our analytic sample is 2004, but the latest available ACCRA data we could obtain is for year 2003. As a result, the prices $P_{g t}$ for the HRS survey year 2004 are calculated using only the 2003 ACCRA data.

To estimate equation (6), we use system generalized method of moments (GMM) (Arellano and Bond 1991; Arellano and Bover 1995; Blundell and Bond 1998), which combines the moment conditions of the differenced equation with moment conditions for the model in levels. The following moment conditions are jointly estimated using the "xtabond2" command in Stata 10:

$$
\begin{aligned}
E\left(W_{i g, k} \Delta \varepsilon_{i g t}\right) & =0, k=1,2, \ldots t-2, t=1, \ldots T \\
E\left(\Delta W_{i g, q}\left(\alpha_{i}+\varepsilon_{i g t}\right)\right) & =0, q=1,2, \ldots t-1 \\
E\left(\Delta P_{g t} \Delta \varepsilon_{i g t}\right) & =0 \\
E\left(\Delta Z_{g t} \Delta \varepsilon_{i g t}\right) & =0 \\
E\left(\Delta X_{i g t} \Delta \varepsilon_{i g t}\right) & =0 .
\end{aligned}
$$

\section{County Characteristics}

Apart from the food price vectors, we include the following county-level characteristics in the regressions: log of price of cigarettes, log of price of gasoline, and $\log$ of price of nonfood goods (excluding cigarettes and gasoline).

Following Chou, Grossman, and Saffer (2004), we include cigarette prices in the weight equation, since cigarettes may serve a weight control function. If smoking reduces weight, cheaper cigarettes might contribute to weight reduction, holding food prices constant.

The effects of the gasoline price are more complex. On the one hand, this affects the cost of transportation and the incentives for exercise. For instance, in areas where gasoline is expensive, people may choose to live closer to work, and take public transportation, both of which involves more exercise than 
driving. The price of gasoline is also correlated with the cost of agricultural output. In principle, this could also absorb some of the cost-driven variation in the price of food: increases in the price of gasoline may increase the cost of producing and transporting food; this may have different effects in different parts of the country. In practice, however, including the price of gasoline had little impact on the estimated effects of food price variation.

Finally, the price of nonfood goods captures the substitution and income effects that occur when the overall cost of living rises.

\section{Individual Characteristics}

We include the following time-varying individual characteristics in our regression models: age, self-reported diagnosis of chronic conditions (cancer, diabetes, heart disease, hypertension, lung disease, stroke, arthritis, mental problems), whether self-rated health is fair or poor; marital status, whether the respondent is working for pay, total household income, total household wealth, and health insurance status.

\subsubsection{Correction for Sample Attrition Bias}

Since we include only 32.0 percent of the initial sample $(3,111$ out of 9,733 unique individuals) in our analysis, sample selection bias may be an issue, in the sense that our analytic sample may no longer be representative of the study population. In particular, the question is whether our sample selection criteria are correlated with food price and weight changes.

To address sample selection bias, we adjust the sampling weights to account for our secondary selection criteria. We first estimate a probit model of whether an individual in the study sample will appear in the analytic sample. Regressors include demographics, health, and economic status at the 1992 interview. We then predict the probability of sample inclusion for those in the analytic sample, and multiply the sampling weight by the inverse of the predicted probability. All descriptive and regression analyses are carried out using the modified sampling weight. This procedure addresses selection bias on the basis of observables, but we may still suffer from selection on the basis of unobservables (Wooldridge 2002).

The selection model is presented in table 3.1. It shows that residing in rural areas greatly decreases the probability of being included in the analytic sample. This is because the ACCRA price data is only collected in cities. Even though we aggregate data at the county level, those in rural counties are excluded. Individuals with diabetes at the baseline interview are also less likely to appear in the analytic sample. In addition, non-Hispanic blacks, Hispanic, and those with less than high school education are more likely to be included. Finally, those with higher household wealth are also more likely to appear in the analytic sample.

The original sampling weight has a mean of 2,340 , standard deviation of 1,048 , a minimum of 563 and a maximum of 7,710. After multiplying by the 
Table 3.1 Probit model of whether being included in the analytic sample

\begin{tabular}{|c|c|}
\hline Covariate & Being included in the analytic sample \\
\hline Male & $\begin{array}{l}-0.025 \\
(0.029)\end{array}$ \\
\hline Non-Hispanic black & $\begin{array}{l}0.303^{* * * *} \\
(0.039)\end{array}$ \\
\hline Hispanic & $\begin{array}{l}0.374 * * * \\
(0.051)\end{array}$ \\
\hline Less than high school & $\begin{array}{l}0.095^{* *} \\
(0.037)\end{array}$ \\
\hline Some college and above & $\begin{array}{c}0.044 \\
(0.032)\end{array}$ \\
\hline Suburban area & $\begin{array}{l}-0.038 \\
(0.031)\end{array}$ \\
\hline Rural area & $\begin{array}{c}-0.775^{* * *} \\
(0.036)\end{array}$ \\
\hline Initial cancer & $\begin{array}{c}0.094 \\
(0.063)\end{array}$ \\
\hline Initial diabetes & $\begin{array}{l}-0.105^{* *} \\
(0.048)\end{array}$ \\
\hline Initial heart disease & $\begin{array}{l}-0.015 \\
(0.047)\end{array}$ \\
\hline Initial hypertension & $\begin{array}{c}0.002 \\
(0.030)\end{array}$ \\
\hline Initial lung disease & $\begin{array}{c}0.020 \\
(0.061)\end{array}$ \\
\hline Initial stroke & $\begin{array}{c}-0.085 \\
(0.088)\end{array}$ \\
\hline Initial arthritis & $\begin{array}{c}0.026 \\
(0.030)\end{array}$ \\
\hline Initial psyche problems & $\begin{array}{c}0.019 \\
(0.054)\end{array}$ \\
\hline Initial current smoking & $\begin{array}{c}-0.006 \\
(0.031)\end{array}$ \\
\hline Initial self-rated health is fair/poor & $\begin{array}{c}0.001 \\
(0.040)\end{array}$ \\
\hline Initial physical activity & $\begin{array}{l}-0.013 \\
(0.034)\end{array}$ \\
\hline Initial age & $\begin{array}{l}0.426^{* * *} \\
(0.161)\end{array}$ \\
\hline Initial age squared & $\begin{array}{l}-0.004 * * * \\
(0.001)\end{array}$ \\
\hline Initial log of household income & $\begin{array}{l}-0.010 \\
(0.011)\end{array}$ \\
\hline Initial non-positive household wealth & $\begin{array}{c}0.042 \\
(0.111)\end{array}$ \\
\hline Initial log of household wealth & $\begin{array}{l}0.022 * * \\
(0.010)\end{array}$ \\
\hline Initial widowed & $\begin{array}{c}-0.022 \\
(0.059)\end{array}$ \\
\hline
\end{tabular}


Table 3.1 (continued)

\begin{tabular}{lc}
\hline Covariate & Being included in the analytic sample \\
\hline Initial single & $0.080^{* *}$ \\
Initial R working for pay & $(0.039)$ \\
& 0.014 \\
Initial any health insurance & $(0.033)$ \\
& -0.017 \\
Constant & $(0.041)$ \\
& $-12.266^{* * *}$ \\
$\mathrm{~N}$ & $(4.460)$ \\
\end{tabular}

Source: Health and Retirement Study 1992-2004, ACCRA 1992-2003.

Note: A probit model is used to model the probability that a HRS respondent who is born between year 1931 and 1941 is included in the analytic sample.

$* * * p<0.01$

$* * p<0.05$

$* p<0.10$

inverse of the probability, the mean is raised to 5,813, the standard deviation 3,560 , the minimum 921 , and the maximum is 26,687 . Descriptive statistics of the analytic sample are shown in table 3.2.

\subsection{Results}

The key outcome variable is either BMI or its natural logarithm. When the outcome variable is BMI (or log BMI), we include in equation (6) the individual's BMI (or log BMI) in the previous two periods as right-hand side control variables. Including two periods is the minimum necessary for an error term without autocorrelation. All regressions also include the following variables: log of price of cigarettes, log price of gasoline, log price of nonfood goods excluding cigarettes and gasoline, self-reported diagnosis of chronic conditions, self-rated health, marital status, whether working for pay, total household income, total household wealth, health insurance status, and time dummies.

In addition to average effects, we are also interested in examining whether there will be heterogeneous food price effects across demographic and socioeconomic subgroups. First, we examine whether the price-weight relationship is stronger for individuals who are obese $\left(B M I \geq 30 \mathrm{~kg} / \mathrm{m}^{2}\right)$ at baseline. If so, this is consistent with the hypothesis that food tax policy better targets those with unhealthy weight. We add baseline obesity interacted with price to equation (6). It is also possible that the poor may be more price-elastic. We thus interact placement in the bottom tercile of baseline household wealth with food prices. 
Table 3.2

Summary statistics

\begin{tabular}{|c|c|c|}
\hline Variable & Mean & Standard deviation \\
\hline Body mass index $\left(\mathrm{kg} / \mathrm{m}^{2}\right)$ & 28.65 & 6.01 \\
\hline \multicolumn{3}{|l|}{ Prices } \\
\hline Price per 1,000 calories & 0.79 & 0.07 \\
\hline Price per 100 grams of fat & 1.79 & 0.21 \\
\hline Price of cigarettes & 15.16 & 4.74 \\
\hline Price of gasoline & 0.78 & 0.08 \\
\hline Price of nonfood items excl.cigarettes and gasoline & 229.39 & 91.41 \\
\hline \multicolumn{3}{|l|}{ Demographics } \\
\hline Age at interview & 61.4 & 4.9 \\
\hline Male & $46.6 \%$ & $49.9 \%$ \\
\hline Hispanic & $6.8 \%$ & $25.1 \%$ \\
\hline Non-Hispanic black & $11.2 \%$ & $31.5 \%$ \\
\hline Less than high school & $21.6 \%$ & $41.2 \%$ \\
\hline Some college and above & $40.3 \%$ & $49.1 \%$ \\
\hline Widowed & $9.7 \%$ & $29.5 \%$ \\
\hline Single & $16.9 \%$ & $37.5 \%$ \\
\hline \multicolumn{3}{|l|}{ Health conditions } \\
\hline Cancer & $9.1 \%$ & $28.8 \%$ \\
\hline Diabetes & $14.2 \%$ & $34.9 \%$ \\
\hline Heart disease & $16.8 \%$ & $37.4 \%$ \\
\hline Hypertension & $43.3 \%$ & $49.6 \%$ \\
\hline Lung disease & $7.4 \%$ & $26.2 \%$ \\
\hline Stroke & $4.2 \%$ & $20.0 \%$ \\
\hline Arthritis & $48.1 \%$ & $50.0 \%$ \\
\hline Psyche problems & $11.2 \%$ & $31.5 \%$ \\
\hline Self-rated health is fair/poor & $22.8 \%$ & $41.9 \%$ \\
\hline \multicolumn{3}{|l|}{ Economic conditions } \\
\hline $\mathrm{R}$ working for pay & $51.4 \%$ & $50.0 \%$ \\
\hline Any health insurance & $91.3 \%$ & $28.2 \%$ \\
\hline $\mathrm{HH}$ total income & 36,407 & 49,739 \\
\hline HH wealth & 242,413 & $1,201,071$ \\
\hline
\end{tabular}

Source: HRS 1992-2004, ACCRA 1992-2003.

Note: Number of individuals: 3,111; Number of observations: 15,027.

\subsubsection{Price Per Calorie and BMI}

First, we examine the relationship between price per calorie and our BMI measures. Table 3.3 analyzes the impact of price per calorie on BMI. The first column shows model estimation without any interaction effects. Current BMI is strongly associated with its two lagged values, demonstrating the persistence of BMI. The coefficient on log price per calorie is negative and statistically significant at the 10 percent level. A 10 percent reduction in price per calorie is associated with a BMI increase of approximately 0.26 units within two years. Coefficients for the other price variables are insignificant.

The second column of table 3.3 shows estimation results with interaction 
Table 3.3 Effect of price per calorie on BMI

\begin{tabular}{|c|c|c|c|}
\hline \multirow[b]{2}{*}{ Independent variable } & \multicolumn{3}{|c|}{ Model specification } \\
\hline & $I$ & $I I$ & III \\
\hline BMI two years ago & $\begin{array}{l}0.672^{* * *} \\
(0.031)\end{array}$ & $\begin{array}{l}0.651^{* * *} \\
(0.036)\end{array}$ & $\begin{array}{l}0.657^{* * *} \\
(0.031)\end{array}$ \\
\hline BMI four years ago & $\begin{array}{l}0.210^{* * * *} \\
(0.026)\end{array}$ & $\begin{array}{l}0.195 * * * \\
(0.027)\end{array}$ & $\begin{array}{l}0.206^{* * *} \\
(0.024)\end{array}$ \\
\hline Log of price per calorie & $\begin{array}{l}-2.568^{*} \\
(1.406)\end{array}$ & $\begin{array}{c}-2.308^{*} \\
(1.395)\end{array}$ & $\begin{array}{c}-1.734 \\
(1.675)\end{array}$ \\
\hline Log of price per calorie $\cdot($ obese at baseline) & & $\begin{array}{c}0.979 \\
(4.038)\end{array}$ & \\
\hline Log of price per calorie $\cdot($ poor at baseline) & & & $\begin{array}{c}-1.771 \\
(2.936)\end{array}$ \\
\hline Log of cigarettes price & $\begin{array}{c}0.566 \\
(0.694)\end{array}$ & $\begin{array}{c}0.464 \\
(0.645)\end{array}$ & $\begin{array}{c}0.573 \\
(0.693)\end{array}$ \\
\hline Log of cigarettes price $\cdot($ obese at baseline) & & $\begin{array}{c}0.387 \\
(0.523)\end{array}$ & \\
\hline $\log$ of cigarettes price $\cdot($ poor at baseline) & & & $\begin{array}{l}-0.215 \\
(0.453)\end{array}$ \\
\hline Log of gasoline price & $\begin{array}{c}0.006 \\
(1.065)\end{array}$ & $\begin{array}{c}-0.268 \\
(0.936)\end{array}$ & $\begin{array}{c}0.302 \\
(1.085)\end{array}$ \\
\hline Log of gasoline price $\cdot$ (obese at baseline) & & $\begin{array}{c}0.849 \\
(1.559)\end{array}$ & \\
\hline Log of gasoline price $\cdot($ poor at baseline) & & & $\begin{array}{c}-0.425 \\
(1.325)\end{array}$ \\
\hline Log of nonfood price & $\begin{array}{c}0.652 \\
(0.579)\end{array}$ & $\begin{array}{c}0.354 \\
(0.515)\end{array}$ & $\begin{array}{c}0.243 \\
(0.588)\end{array}$ \\
\hline Log of nonfood price $\cdot($ obese at baseline) & & $\begin{array}{l}-0.702 \\
(0.475)\end{array}$ & \\
\hline Log of nonfood price $\cdot($ poor at baseline) & & & $\begin{array}{c}0.807^{*} \\
(0.477)\end{array}$ \\
\hline$N$ & 8,231 & 8,231 & 8,231 \\
\hline
\end{tabular}

Source: Health and Retirement Study, 1992-2004, ACCRA price data, 1992-2003. Models are estimated using system GMM. All models also include the following variables: self-rated health, chronic conditions, working status, marital status, household income and household wealth, health insurance status, and year dummies.

$* * * p<0.01$

$* * p<0.05$

$* p<0.10$

terms between being obese at baseline and price variables. The main effect of price per calorie remains significant but the interaction term is insignificant, suggesting statistically similar food price-BMI relationships for the obese and nonobese. Estimation in the last column of table 3.3 includes interaction terms between being poor at baseline-defined as being at the bottom tercile of the household distribution - and price variables. Both the main and interaction term of $\log$ of per calorie are negative, but insignificant. 
Table 3.4 shows the effect of price per calorie on $\log$ BMI. The coefficients can be interpreted as elasticities. The first column shows the estimation without any interaction terms. The coefficient on the log of price per calorie is negatively and statistically significant at 10 percent level. Quantitatively, a 10 percent reduction in price per calorie is associated with a 0.77 percent reduction in BMI within two years. The next two columns confirm the results

Table 3.4

Effect of price per calorie on $\log \mathrm{BMI}$

\begin{tabular}{|c|c|c|c|}
\hline \multirow[b]{2}{*}{ Independent variable } & \multicolumn{3}{|c|}{ Model specification } \\
\hline & $I$ & $I I$ & III \\
\hline Log of BMI two years ago & $\begin{array}{l}0.654^{* * * *} \\
(0.030)\end{array}$ & $\begin{array}{l}0.593^{* * *} \\
(0.048)\end{array}$ & $\begin{array}{l}0.641^{\text {**** }} \\
(0.031)\end{array}$ \\
\hline Log of BMI four years ago & $\begin{array}{l}0.195^{* * *} \\
(0.023)\end{array}$ & $\begin{array}{l}0.171^{* * * *} \\
(0.025)\end{array}$ & $\begin{array}{l}0.200^{* * * *} \\
(0.023)\end{array}$ \\
\hline Log of price per calorie & $\begin{array}{c}-0.077^{*} \\
(0.046)\end{array}$ & $\begin{array}{c}-0.074 \\
(0.048)\end{array}$ & $\begin{array}{l}-0.047 \\
(0.054)\end{array}$ \\
\hline Log of price per calorie (obese at baseline) & & $\begin{array}{c}0.032 \\
(0.116)\end{array}$ & \\
\hline Log of price per calorie $\cdot($ poor at baseline) & & & $\begin{array}{c}-0.089 \\
(0.094)\end{array}$ \\
\hline Log of cigarettes price & $\begin{array}{c}0.020 \\
(0.022)\end{array}$ & $\begin{array}{c}0.015 \\
(0.022)\end{array}$ & $\begin{array}{c}0.020 \\
(0.022)\end{array}$ \\
\hline Log of cigarettes price $\cdot$ (obese at baseline) & & $\begin{array}{c}0.013 \\
(0.014)\end{array}$ & \\
\hline Log of cigarettes price $\cdot($ poor at baseline) & & & $\begin{array}{l}-0.009 \\
(0.014)\end{array}$ \\
\hline Log of gasoline price & $\begin{array}{c}-0.006 \\
(0.032)\end{array}$ & $\begin{array}{c}-0.015 \\
(0.031)\end{array}$ & $\begin{array}{c}-0.002 \\
(0.034)\end{array}$ \\
\hline Log of gasoline price $\cdot$ (obese at baseline) & & $\begin{array}{c}0.029 \\
(0.043)\end{array}$ & \\
\hline Log of gasoline price $\cdot($ poor at baseline) & & & $\begin{array}{c}0.003 \\
(0.041)\end{array}$ \\
\hline Log of nonfood price & $\begin{array}{c}0.019 \\
(0.018)\end{array}$ & $\begin{array}{c}0.016 \\
(0.018)\end{array}$ & $\begin{array}{c}0.003 \\
(0.018)\end{array}$ \\
\hline $\log$ of nonfood price $\cdot$ (obese at baseline) & & $\begin{array}{c}-0.026^{*} \\
(0.014)\end{array}$ & \\
\hline Log of nonfood price $\cdot($ poor at baseline) & & & $\begin{array}{c}0.028^{* *} \\
(0.014)\end{array}$ \\
\hline $\mathrm{N}$ & 8,231 & 8,231 & 8,231 \\
\hline
\end{tabular}

Source: Health and Retirement Study, 1992-2004, ACCRA price data, 1992-2003. Models are estimated using system GMM. All models also include the following variables: self-rated health, chronic conditions, working status, marital status, household income and household wealth, health insurance status, and year dummies.

$* * * p<0.01$

$* * p<0.05$

$* p<0.10$ 
in table 3.4 that the food price effect does not differ by either baseline BMI status or baseline household wealth.

Even if the entire estimated effect is causal, the short-term effect of price per calorie on BMI appears relatively small. A one-standard deviation, or 10 percent, reduction in price is associated with a BMI increase of 0.26 units, or 0.77 percent. By way of comparison, clinical guidelines suggest 10 percent BMI reductions as the minimum necessary for clinically meaningful health benefits to overweight individuals.

The long-run effect of price per calorie may be larger, but still below the threshold of clinical significance. Once again presuming that our entire estimate is causal, figure 3.2 and figure 3.3 show the simulated changes in BMI, both in levels and in percentages, due to a permanent 10 percent reduction in price per calorie. After ten years, the price reduction will be associated with a BMI increase of 1.05 units (or 2.5 percent). If we extrapolate to the model's implied long-run steady-state, these figures rise to 2.2 units of BMI (or 5.1 percent), still quite modest from a clinical perspective. Of course, applied to the entire population, this is a nontrivial effect, compared to the total growth in mean BMI over the last several decades.

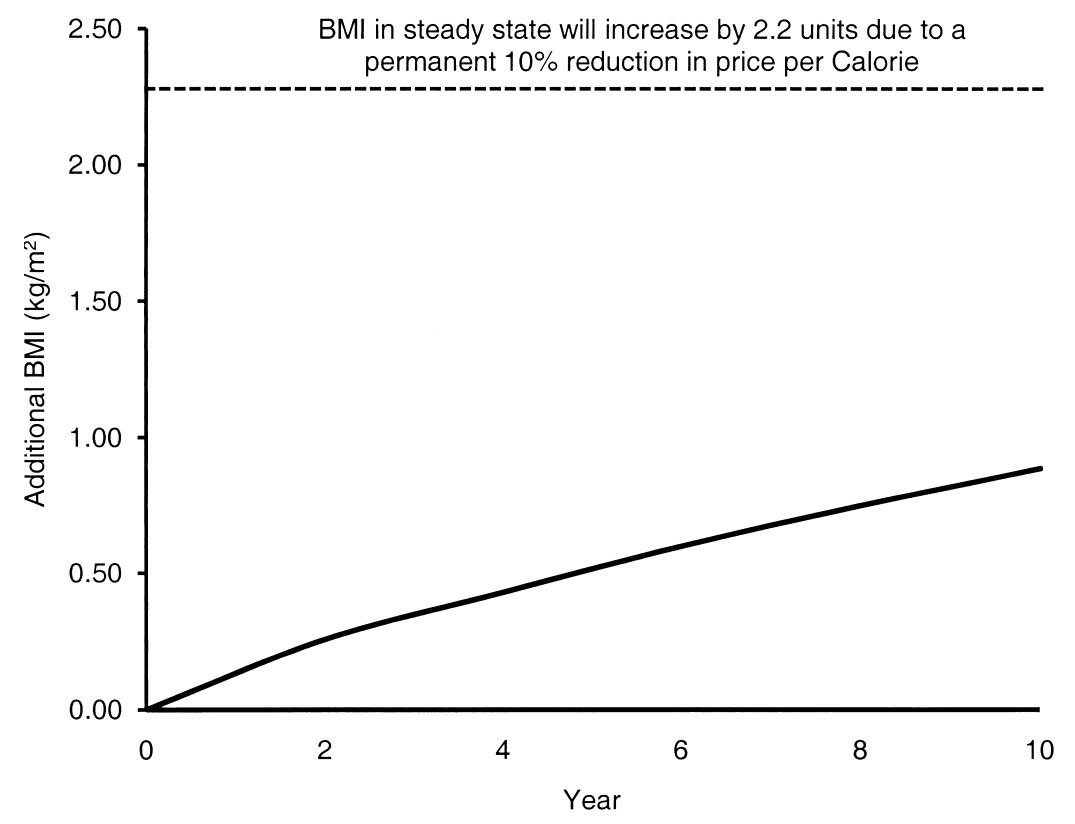

Fig. 3.2 Additional BMI due to a permanent 10 percent reduction in price per calorie

Note: This figure shows the simulated effect of a permanent 10 percent reduction in price per calorie on BMI trajectory over ten years, based on the estimates shown in the first column of table 3.3. 


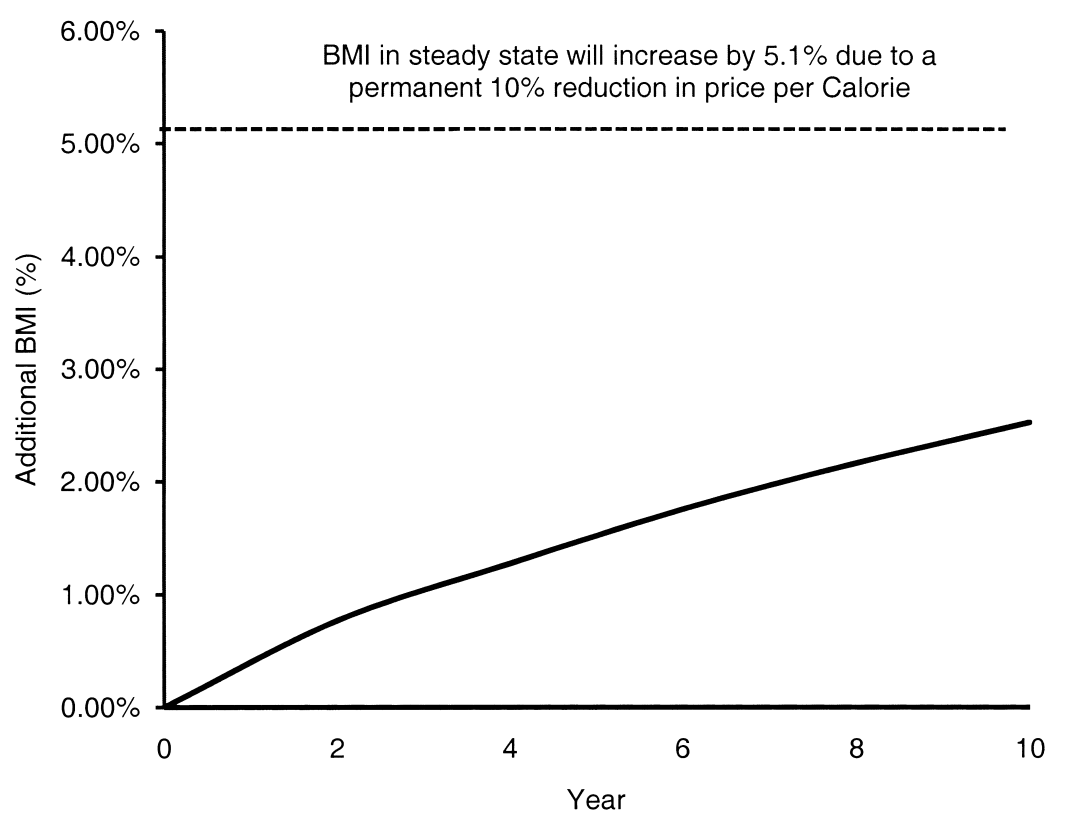

Fig. 3.3 Additional BMI as a percentage of total BMI due to a permanent $10 \%$ reduction in price per calorie

Note: This figure shows the simulated effect of a permanent 10 percent reduction in price per calorie on additional BMI as a percentage of total BMI, over ten years, based on the estimates shown in the first column of table 3.4 .

\subsubsection{Comparisons to the Previous Literature}

The majority of the previous literature has examined the short-term effects of food prices on body weight. Our results for the short-term relationship between prices and BMI appear to be roughly in line with the literature that focuses on other subpopulations. We estimate that the short-term elasticity between the price of calories and body weight is -0.077 . For at-home food, Chou, Grossman, and Saffer (2004) estimated a price elasticity of -0.04. Gelbach, Klick, and Stratmann (2007) find that doubling the price of "unhealthy" food is associated with about 1 percent less BMI.

We found that the effect of food prices on weight grow over time. Sturm and Datar (2008) also found that the effect of food prices on body weight gain among children became larger during a five-year period, relative to the effect during a three-year period.

\subsubsection{Identification}

Our models are identified by local trends in food prices. The data reveal substantial variation across regions in local price trends. It is natural to 
inquire into the sources of these, but quite difficult to pinpoint an exact origin. We investigated several hypotheses.

Several studies have found that store formats are important in explaining cross-sectional regional price variations. One study found that food sold at Walmart is on average about 15 percent to 25 percent cheaper than traditional supermarkets (Hausman and Leibtag 2004). Another study examined the effects of Walmart entry on the city-level prices of several nonfood retail items, including aspirin, cigarettes, soft drinks, detergent, and others. The author found negative price effects of Walmart entrance (Basker 2005). Motivated by this result, we assessed whether geographic variation in the appearance of Walmart entry generated significant differences in local price trends. This failed to provide much, if any, explanatory power.

Second, we tested the hypothesis that some areas were more exposed to increases in transportation costs for food. To test this, we tested for systematic price trend differences across states with large and small shares of agricultural land. To be sure, this is a fairly crude measure of local transportation costs. Perhaps due to this error in measurement, we failed to find systematic differences in price trends across areas with more or less agricultural land and agricultural output.

A third option, related to transportation costs, exploits variation in the price of gasoline (Gelbach, Klick, and Stratmann 2007). The Gelbach et al. study has found that census-region level price variation in gasoline influence, the relative price of healthy food. Moreover, while gasoline can affect incentives to exercise, its effects on the cost of transporting goods should vary systematically across the country, depending on how far retailers are from production sites. This serves as a source of identification that "nets out" the common impact on exercise, and isolates the impact on transportation costs.

Following this reasoning, we used the interactions of gasoline price and approximate measures of per capita food production (proportion of population employed in food manufacturing, and per capita farm area, proportion of land arable) as the instruments for food prices. First-stage results were roughly consistent with our assumptions - the interactions of gasoline price and per capita food output measures have significant and negative effects on price per calorie. However, including the interactions as instruments in the system GMM estimation raised the standard error substantially, and the effect of price per calorie becomes positive and statistically insignificant. One interpretation is that the gasoline instrument introduces too much noise to be useful.

The failure to identify a clean source of variation begs the question of whether price trends are correlated with other economic or social factors that also influence weight. As a partial test of this, we assessed the impact of including observable health and economic factors on the price coefficients 
of interest. We reestimated models for the effect of price per calorie on BMI by dropping all health and economic factors. The results are shown in table 3C.1. They are very similar to those in table 3.3. The effect of price per calorie on $\log$ BMI is also very robust to inclusion or exclusion of health and economic factors (results not shown).

\subsubsection{Limitations}

First, as discussed earlier, local variation in food prices might not be exogenous. If the supply of food is upward-sloping (i.e., if food prices are not primarily cost-driven), the resulting simultaneity between supply and demand would create downward bias in our estimated price effects. Testing this possibility would require a plausibly valid instrument, but these are in short supply here. We explored several candidates. First, fuel prices may influence the supply of food and ultimately body weight. However, they may also influence incentives for exercise, and thus the demand for weight. Moreover, the first-stage relationships between local trends in fuel prices and local trends in food prices are - perhaps not surprisingly — quite weak. A second candidate is local weather variation, particularly extreme weather events. These may affect the costs of distribution and transportation of food. However, such major events also have a variety of additional causal effects that can impact exercise, metabolism, and economic status. In the absence of an instrument, we have presented evidence that observed variation in economic and demographic factors are unrelated to local trends in price. It remains possible that unobserved variation in these factors is still correlated with price.

As a result of these issues, it is possible that our effects combine both selective and causal factors. In discussing the implications of our findings, we have presumed that selection is likely to enlarge our estimates, which would then be upper bounds on the causal impacts. The idea is that heavier individuals will be likely to select into areas with cheaper food. If this assumption fails, it is possible that the causal impact of price on BMI is much larger than we have estimated.

One concern here is the possibility of measurement error in food prices. As is typically the case with the analysis of price effects, measurement error is another important issue. The ACCRA price data are based on sampling a number of local stores, but intracity price variation may not be adequately captured. More generally, it is quite difficult to measure the basket of prices faced by a particular individual who lives in a particular part of a city. This may result in downward bias that could partially, or even completely, offset the effects of selection.

Finally, we have the common problem of measurement error in weight. Our approach was to correct for self-reporting bias using a subsample of HRS respondents for whom data are available on measured weight and selfreported weight. Following Cawley (1999), we impute the expected measure- 
ment error in self-reported weight for the rest of the sample. Naturally, this strategy does not purge the measurement error; it merely mitigates it, to the extent that our imputation contains some relevant information. This would be a problem if error in reporting were correlated with price trends. Unfortunately, we cannot test this directly, because we do not have a panel of data on reporting error, which is only measured in one wave of the HRS data.

\subsection{Conclusions}

We examined both the short-term and long-term relationships between food prices of various kinds and body weight. We found very modest shortterm relationships between price per calorie on body weight, and the magnitudes align with the previous literature. We do not find differential effects of price per calorie by baseline obesity or baseline household wealth. The long-term effect is larger, but still below the threshold of clinical significance. Within ten years, a 10 percent permanent reduction in price per calorie would be associated with a BMI increase of 1.05 units (or 2.5 percent). The maximum long-run effect implied by the model is still modest, at 2.2 units of BMI (or 5.1 percent).

From a policy perspective, these results suggest that policies raising the price of calories may have little effect on weight in the short term. They may curb the rate of growth somewhat more over a longer period of time. From 1980 to 2000, the average BMI of American adults increased by about 2.7 BMI units (Chou, Grossman, and Saffer 2004). Based on our estimates, a 10 percent increase in the price per calorie would have the potential to roll back 38 percent of this growth within ten years. As we have emphasized, however, caution is warranted in inferring causality from our estimates.

At a minimum, policymakers interested in reducing body weight will not find a fat tax to be a quickly effective solution. Indeed, significant weight reductions are likely to postdate the decision-making horizon of an elected official. However, from a positive point of view, our results suggest the importance of treating weight as a dynamic process, and emphasize the cumulative effects of economic incentives on body weight. 


\section{Appendix A}

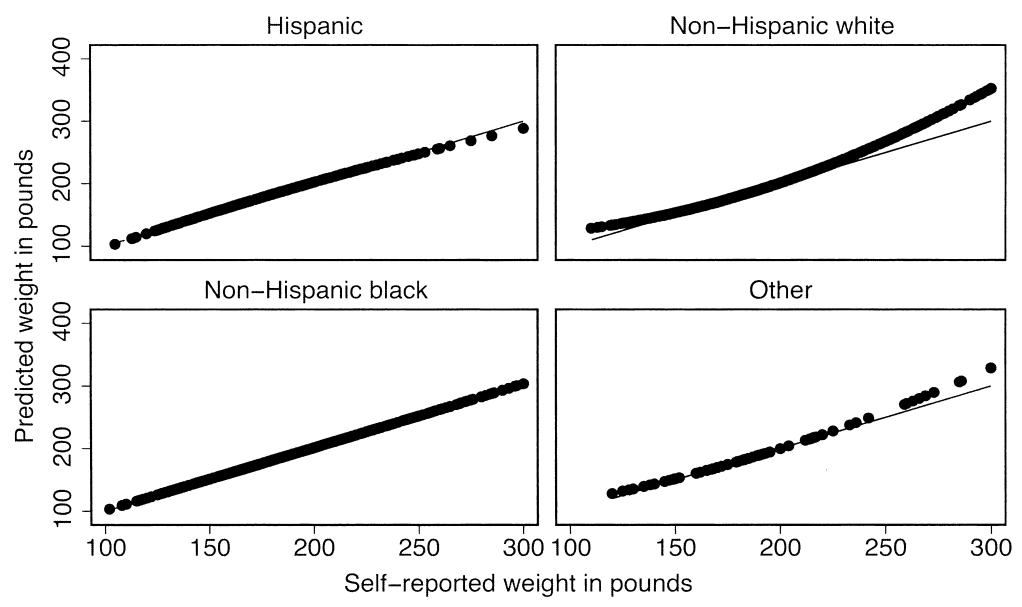

- Predicted - 45-degree line

Fig. 3A.1 Compare predicted and self-reported weight among females (graphs by race/ethnicity)

Notes: Weight prediction is based on the ordinary least squares (OLS) regressions of measured weight against self-reported weight and self-reported weight squared, age and age squared, and predicted at the mean age, by gender and race. The estimation sample includes respondents aged 52 and over in the 2006 HRS survey and with both self-reported and measured weight. Height prediction is based on the OLS regressions of measured height against self-reported height and self-reported height squared, age and age squared, and predicted at the mean age, by gender and races. The estimation sample includes respondents aged 52 and over in the 2006 HRS survey and with both self-reported and measured height.

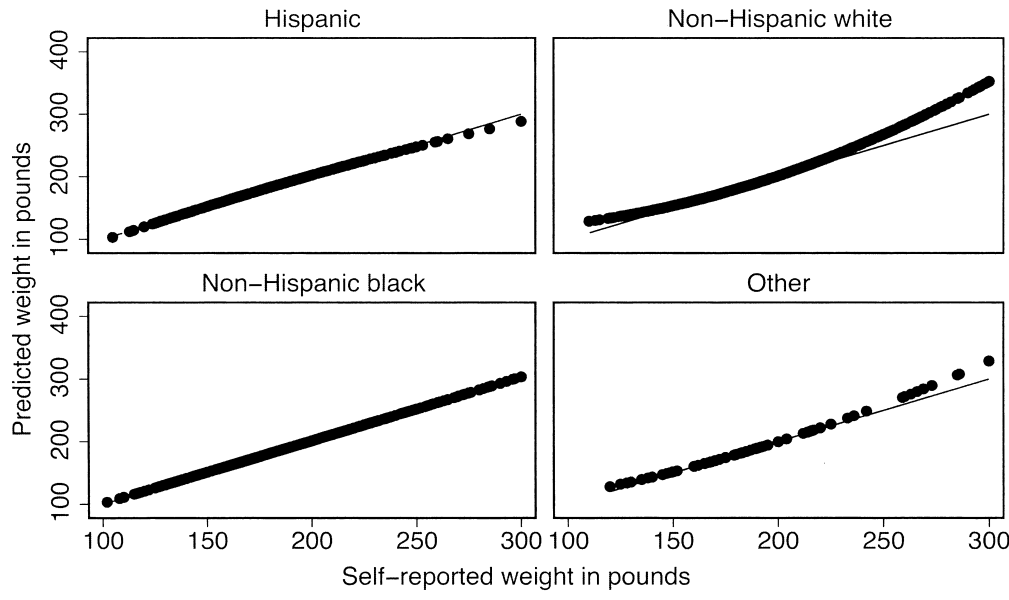

- Predicted - 45-degree line

Fig. 3A.2 Compare predicted and self-reported weight among males (graphs by race/ethnicity)

Note: See notes to figure 3A.1. 


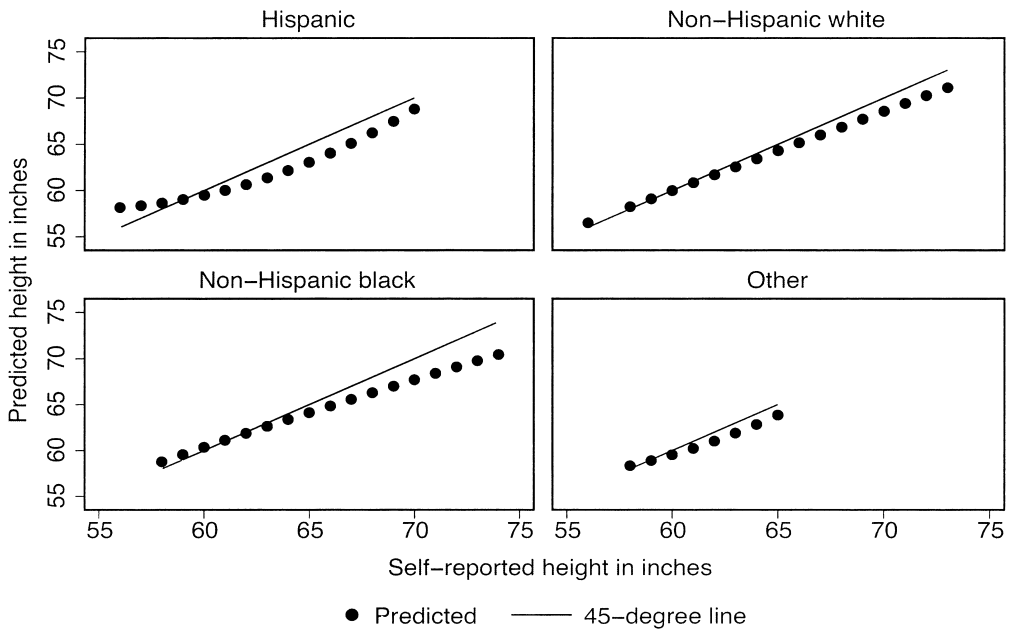

Fig. 3A.3 Compare predicted and self-reported height among females (graphs by race/ethnicity)

Note: See notes to figure 3A.1.

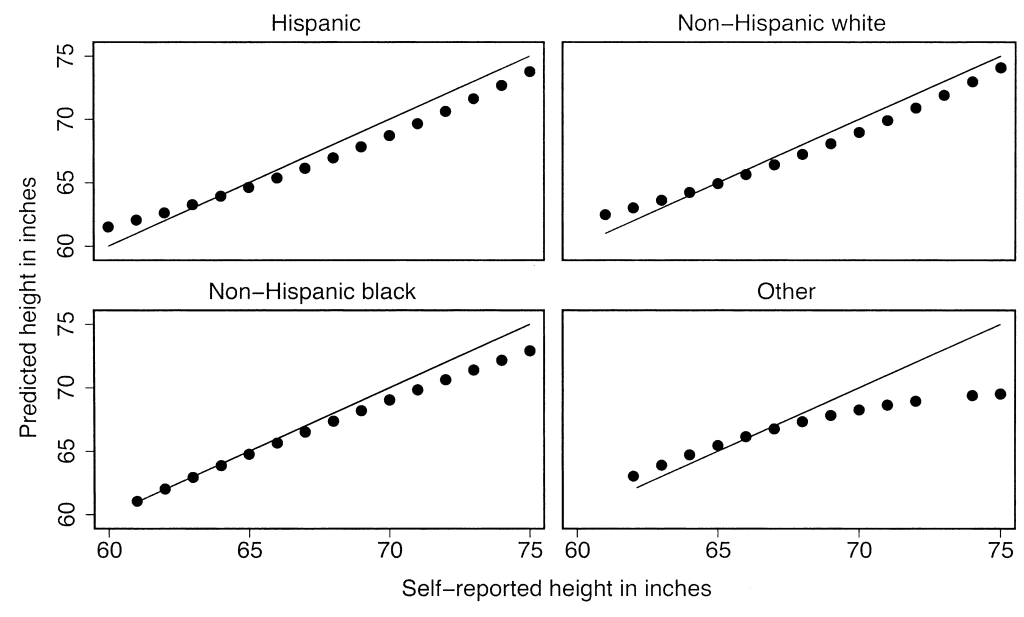

- Predicted 45-degree line

Fig. 3A.4 Compare predicted and self-reported height among males (graphs by race/ethnicity)

Note: See notes to figure 3A.1. 


\section{Appendix B}

Table 3B.1

Items, descriptions, and expenditure shares for ACCRA data collected in year 1992

Expenditure share

within each category

Item

Item description

0.0527

0.0527

0.0492

0.0371

0.0306

0.0494

0.009

0.0376

0.0376

0.0228

0.0474

0.0228

0.0818

0.0748

0.0513

0.0314

0.0419

0.0072

0.0072

0.0333

0.0221

0.0417

0.0184

0.0384

0.0072

0.056

0.0384

0.2631

0.7369
T-Bone steak

Grocery (expenditure share 13\%)

Ground beef or hamburger

Sausage

Frying chicken

Chunk light tuna

Whole milk

Eggs

Margarine

Parmesan cheese, grated

Potatoes

Bananas

Iceberg lettuce

Bread, white

Cigarettes

Coffee, vacuum-packed

Sugar

Corn flakes

Sweet peas

Tomatoes

Peaches

Facial tissues

Washing powder

Shortening

Frozen orange juice

Frozen corn

Baby food

Soft drink Folgers
Price per pound

Price per pound, lowest price

Price per pound; Jimmy Dean $100 \%$ pork

Price per pound, whole fryer

6.125-6.5 oz can, Starkist or Chicken of the Sea, packed in oil

Half-gallon carton

One dozen, grade A, large

One pound, cubes, Blue Bonnet or Parkay

8 oz. canister, Kraft brand

10 pound sack, white or red

Price per pound

Head, approximately 1.25 pounds

$24 \mathrm{oz}$. loaf, lowest price, or prorated 24-oz. equivalent, lowest price

Carton, Winston, king-size $(85 \mathrm{~mm}$.)

13 oz. can, Maxwell House, Hills Brothers, or

5 pounds, cane or beet, lowest price

18 oz., Kellogg's or Post Toasties

15-17 oz. can, Del Monte or Green Giant

14-1/2 oz. can, Hunt's or Del Monte

29 oz. can, Hunt's, Del Monte, or Libby's, halves or slices

175-count box, Kleenex brand

42 oz. ("Ultra"), Tide, Bold, or Cheer

3 pound can, all-vegetable, Crisco brand

12 oz. can, Minute Maid brand

10 oz. can, whole kernel, lowest price

4-4.5 oz. jar, strained vegetables, lowest price

2 liter Coca-Cola, excluding any deposit

Housing (expenditure share 28\%)

Apartment, monthly rent Two-bedroom, unfurnished, excluding all utilities except water, 1-1/2 baths,

Total purchase price approximately 950 sq. ft.

Mortgage rate

1,800 sq. ft. living area new house, 8,000 sq. ft. lot, urban area with all utilities

Effective rate, including points and origination fee, for 30-year conventional fixed- or adjustable-rate mortgage

Principal and interest, using mortgage rate from item $29 \mathrm{~B}$ and assuming $25 \%$ down payment 


\begin{tabular}{|c|c|c|}
\hline $\begin{array}{l}\text { Expenditure share } \\
\text { within each category }\end{array}$ & Item & Item description \\
\hline \multicolumn{3}{|c|}{ Utilities (expenditure share 9\%) } \\
\hline \multirow[t]{3}{*}{0.9} & $\begin{array}{l}\text { Total home } \\
\text { energy cost }\end{array}$ & $\begin{array}{l}\text { Monthly cost, at current rates, for average } \\
\text { monthly consumption of all types of energy } \\
\text { during the previous } 12 \text { months for the type of } \\
\text { home specified in item 29A }\end{array}$ \\
\hline & Electricity & $\begin{array}{l}\text { Average monthly cost for all-electric homes is } \\
\text { shown in column } 30 \mathrm{~A} \text {; average monthly cost } \\
\text { for homes using other types of energy as well } \\
\text { is shown in column } 30 \mathrm{~B}\end{array}$ \\
\hline & $\begin{array}{l}\text { Other home } \\
\text { energy }\end{array}$ & $\begin{array}{l}\text { Average monthly cost at current rates for natural } \\
\text { gas, fuel oil, coal, wood, and any other forms } \\
\text { of energy except electricity }\end{array}$ \\
\hline 0.1 & Telephone & $\begin{array}{l}\text { Private residential line; customer owns } \\
\text { instruments. Price includes: basic monthly } \\
\text { rate; additional local use charges, if any, } \\
\text { incurred by a family of four; Touch Tone fee; } \\
\text { all other mandatory monthly charges, such as } \\
\text { long distance access fee and } 911 \text { fee; and all } \\
\text { taxes foregoing }\end{array}$ \\
\hline \multicolumn{3}{|c|}{ Transportation (expenditure share $10 \%$ ) } \\
\hline 0.1 & Commuter fare & One-way commuting fare, up to ten miles \\
\hline 0.3541 & $\begin{array}{l}\text { Auto } \\
\text { maintenance }\end{array}$ & $\begin{array}{l}\text { Average price to computer-or spin balance- } \\
\text { one front wheel }\end{array}$ \\
\hline 0.5459 & Gasoline & $\begin{array}{l}\text { One gallon regular unleaded, national brand, } \\
\text { including all taxes; cash price at self-service } \\
\text { pump if available }\end{array}$ \\
\hline \multicolumn{3}{|c|}{ Health Care (expenditure share $5 \%$ ) } \\
\hline 0.175 & Hospital room & Average cost per day for semiprivate room \\
\hline 0.3509 & $\begin{array}{l}\text { Office visit, } \\
\text { doctor }\end{array}$ & $\begin{array}{l}\text { American Medical Association procedure } 90050 \text { : } \\
\text { general practitioner's routine examination of } \\
\text { established patient }\end{array}$ \\
\hline 0.3509 & $\begin{array}{l}\text { Office visit, } \\
\text { dentist }\end{array}$ & $\begin{array}{l}\text { American Dental Association procedure } 1110 \\
\text { (adult teeth cleaning) and } 0120 \text { (periodic oral } \\
\text { examination) }\end{array}$ \\
\hline 0.1232 & Aspirin & 100 table bottle, Bayer brand, $325 \mathrm{mg}$. tablets \\
\hline
\end{tabular}




\begin{tabular}{|c|c|c|}
\hline $\begin{array}{l}\text { Expenditure share } \\
\text { within each category }\end{array}$ & Item & Item description \\
\hline \multicolumn{3}{|c|}{ Miscellaneous (expenditure share 35\%) } \\
\hline 0.095 & $\begin{array}{r}\text { Hamburger } \\
\text { sandwich }\end{array}$ & $\begin{array}{l}\text { 1/4 pound patty with cheese, pickle, onion, } \\
\text { mustard, and catsup. McDonald's Quarter- } \\
\text { Pounder with Cheese, where available }\end{array}$ \\
\hline 0.095 & Pizza & $\begin{array}{l}12^{\prime \prime}-13^{\prime \prime} \text { thin crust cheese pizza. Pizza Hut or } \\
\text { Pizza Inn, where available }\end{array}$ \\
\hline 0.095 & Fried chicken & $\begin{array}{l}\text { Thigh and drumstick, with or without extras, } \\
\text { whichever is less expensive. Kentucky Fried } \\
\text { Chicken or Church's where available }\end{array}$ \\
\hline 0.0174 & Haircut & Man's barber shop haircut, no styling \\
\hline 0.0174 & Beauty salon & Woman's shampoo, trim, and blow dry \\
\hline 0.0174 & Toothpaste & 6 oz-7 oz. tube, Crest or Colgate \\
\hline 0.0174 & Shampoo & 15 oz. bottle, Alberto VO-5 \\
\hline 0.0174 & Dry cleaning & Man's two-piece suit \\
\hline 0.115 & Man's dress shirt & $\begin{array}{l}\text { Arrow, Enro, Van Heusen, or J.C. Penney's } \\
\text { Stafford. White, cotton/polyester blend (at } \\
\text { least } 55 \% \text { cotton), long sleeves }\end{array}$ \\
\hline 0.0523 & Boy's underwear & $\begin{array}{l}\text { Package of three briefs, size } 10-14 \text {, cotton, } \\
\text { lowest price }\end{array}$ \\
\hline 0.115 & Man's denim jeans & $\begin{array}{l}\text { Levi's brand, } 501 \mathrm{~s} \text { or } 505 \mathrm{~s} \text {, rinsed, washed, or } \\
\text { bleached, size } 28 / 30-34 / 36\end{array}$ \\
\hline 0.0742 & $\begin{array}{l}\text { Major appliance } \\
\text { repair }\end{array}$ & $\begin{array}{l}\text { Home service call, clothes washing machine; } \\
\text { minimum labor charge, excluding parts }\end{array}$ \\
\hline 0.0271 & $\begin{array}{l}\text { Newspaper } \\
\text { subscription }\end{array}$ & $\begin{array}{l}\text { Daily and Sunday home delivery, large-city } \\
\text { newspaper }\end{array}$ \\
\hline 0.459 & Movie & First-run, indoor, evening, no discount \\
\hline 0.459 & Bowling & Price per line (game), evening rate \\
\hline 0.0654 & Tennis balls & $\begin{array}{l}\text { Can of three extra duty, yellow, Wilson or } \\
\text { Penn Brand }\end{array}$ \\
\hline 0.0384 & Board game & Parker Brothers "Monopoly," no. 9 edition \\
\hline 0.0163 & Liquor & J\&B Scotch, $750 \mathrm{ml}$. bottle \\
\hline 0.0162 & Beer & $\begin{array}{l}\text { Budweiser or Miller Lite, 6-pack, } 12 \mathrm{oz} \text {. } \\
\text { containers, excluding any deposit }\end{array}$ \\
\hline 0.0163 & Wine & Gallo chablis blanc, $1.5 \mathrm{~L}$ bottle \\
\hline
\end{tabular}

Source: Council for Community and Economic Research (C2ER) — formerly known as ACCRA. 


\section{Appendix C}

Table 3C.1

Effect of price per gram of calorie on log BMI, without controlling for health or demographic variables

\begin{tabular}{|c|c|c|c|}
\hline \multirow[b]{2}{*}{ Independent variable } & \multicolumn{3}{|c|}{ Model specification } \\
\hline & $I$ & $I I$ & $I I I$ \\
\hline BMI two years ago & $\begin{array}{l}0.680^{* * * *} \\
(0.029)\end{array}$ & $\begin{array}{l}0.653 * * * \\
(0.034)\end{array}$ & $\begin{array}{l}0.664 * * * \\
(0.030)\end{array}$ \\
\hline BMI four years ago & $\begin{array}{l}0.216^{* * *} \\
(0.025)\end{array}$ & $\begin{array}{l}0.198^{* * * *} \\
(0.027)\end{array}$ & $\begin{array}{l}0.210^{* * * *} \\
(0.024)\end{array}$ \\
\hline Log of price per calorie & $\begin{array}{c}-2.571^{*} \\
(1.409)\end{array}$ & $\begin{array}{c}-2.518^{*} \\
(1.381)\end{array}$ & $\begin{array}{c}-1.811 \\
(1.709)\end{array}$ \\
\hline Log of price per calorie $\cdot$ (obese at baseline) & & $\begin{array}{c}2.041 \\
(3.983)\end{array}$ & \\
\hline Log of price per calorie $\cdot($ poor at baseline) & & & $\begin{array}{l}-1.237 \\
(2.974)\end{array}$ \\
\hline Log of cigarettes price & $\begin{array}{c}0.544 \\
(0.709)\end{array}$ & $\begin{array}{c}0.401 \\
(0.650)\end{array}$ & $\begin{array}{c}0.581 \\
(0.701)\end{array}$ \\
\hline Log of cigarettes price $\cdot($ obese at baseline) & & $\begin{array}{c}0.257 \\
(0.525)\end{array}$ & \\
\hline $\log$ of cigarettes price $\cdot($ poor at baseline) & & & $\begin{array}{c}-0.395 \\
(0.442)\end{array}$ \\
\hline Log of gasoline price & $\begin{array}{l}-0.107 \\
(1.076)\end{array}$ & $\begin{array}{l}-0.233 \\
(0.945)\end{array}$ & $\begin{array}{c}0.193 \\
(1.106)\end{array}$ \\
\hline Log of gasoline price $\cdot($ obese at baseline) & & $\begin{array}{c}0.640 \\
(1.567)\end{array}$ & \\
\hline Log of gasoline price $\cdot($ poor at baseline) & & & $\begin{array}{c}-0.306 \\
(1.308)\end{array}$ \\
\hline Log of nonfood price & $\begin{array}{c}0.768 \\
(0.592)\end{array}$ & $\begin{array}{c}0.422 \\
(0.517)\end{array}$ & $\begin{array}{c}0.259 \\
(0.588)\end{array}$ \\
\hline $\log$ of nonfood price $\cdot$ (obese at baseline) & & $\begin{array}{c}-0.753^{*} \\
(0.452)\end{array}$ & \\
\hline Log of nonfood price $\cdot($ poor at baseline) & & & $\begin{array}{l}0.976^{* *} \\
(0.446)\end{array}$ \\
\hline$N$ & 8,231 & 8,231 & 8,231 \\
\hline
\end{tabular}

Source: Health and Retirement Study, 1992-2004, ACCRA price data, 1992-2003.

Notes: All models also include the following variables: year dummies, self-rated health, chronic conditions, working status, marital status, household income and household wealth.

$* * * p<0.01$

$* * p<0.05$

${ }^{*} p<0.10$ 


\section{References}

Arellano, M., and S. Bond. 1991. Some tests of specification for panel data: Monte Carlo evidence and an application to employment equations. Review of Economic Studies 58 (2): 277-97.

Arellano, M., and O. Bover. 1995. Another look at the instrumental variable estimation of error-components models. Journal of Econometrics 68 (1): 29-51.

Auld, M., and L. Powell. 2008. Economics of food energy density and adolescent body weight. Economica 76 (304): 719-40.

Basker, E. 2005. Selling a cheaper mousetrap: Wal-Mart's effect on retail prices. Journal of Urban Economics 58 (2): 203-29.

Blundell, R., and S. Bond. 1998. Initial conditions and moment restrictions in dynamic panel data models. Journal of Econometrics 87 (1): 115-43.

Cawley, J. 1999. Obesity and addiction. Phd diss. University of Chicago, Chicago, IL.

Chou, S.-Y., M. Grossman, and H. Saffer. 2004. An economic analysis of adult obesity: Results from the behavioral risk factor surveillance system. Journal of Health Economics 23 (3): 565-87.

Gelbach, J. B., J. Klick, and T. Stratmann. 2007. Cheap donuts and expensive broccoli: The effect of relative prices on obesity. Available at SSRN: http://ssrn .com/abstract-976484.

Hausman, J., and E. Leibtag. 2004. CPI bias from supercenters: Does the BLS know that Wal-Mart exists? NBER Working Paper no. 10712. Cambridge, MA: National Bureau of Economic Research, August.

Heo, M., M. S. Faith, and A. Pietrobelli. 2002. Resistance to change of adulthood body mass index. International Journal of Obesity 26 (10): 1404-5.

Jacobson, M. F., and K. D. Brownell. 2000. Small taxes on soft drinks and snack foods to promote health. American Journal of Public Health 90 (6): 854-7.

Lakdawalla, D. N., and T. J. Philipson. 2002. Technological change and the growth of obesity. NBER Working Paper no. 8946. Cambridge, MA: National Bureau of Economic Research, May.

Nestle, M., and M. F. Jacobson. 2000. Halting the obesity epidemic: A public health policy approach. Public Health 115 (1): 12-24.

Sturm, R., and A. Datar. 2005. Body mass index in elementary school children, metropolitan area food prices and food outlet density. Public Health 119 (12): 1059-68.

2008. Food prices and weight gain during elementary school: 5-year update. Public Health 122 (11): 1140-3.

Wooldridge, J. M. 2002. Econometric analysis of cross section and panel data. Cambridge and London: MIT Press. 